\title{
Maciej Pieczyński, Jak nas piszq cyrylica. Polski pan, okupant i faszysta oknem na Zachód?. Warszawa: Fronda PL, 2018, 424 s.
}

$\mathrm{K}$

siążka Macieja Pieczyńskiego ma na okładce inny podtytuł niż na stronie wewnętrznej, w wydawniczej czwórce pojawia się bowiem podtytuł Białorusini, Rosjanie i Ukraińcy o Polakach. Oba są jednak zgodne z treścią pracy. Na ostatniej stronie okładki możemy przeczytać słowa warte przytoczenia:

Lubimy patrzeć na Wschód z policentrycznego punktu widzenia. Oczekujemy, wymagamy, oburzamy się, choć nie zawsze rozumiemy. Ukrainę albo kochamy, albo nienawidzimy. Białoruś jest nam obojętna, a na Rosję patrzymy z wybuchową mieszanką strachu i pogardy. A może by zapytać, co oni o nas myślą i dlaczego? Autor potrafił dotrzeć do tuzów politycznej sceny krajów położonych za Bugiem i zadawać im niewygodne pytania (inna rzecz, że oni potrafili odwzajemniać się nieprzyjemnymi ripostami).

Pieczyński, mimo że należy do młodego pokolenia Polaków, które częstą znajomość rosyjskiego - nawet jeśli tylko podstawową - swoich rodziców zastąpiło angielszczyzną, rosyjski zna. Jest bowiem z wykształcenia nie tylko politologiem, ale i filologiem rosyjsko-ukraińskim oraz doktorem literaturoznawstwa. To umożliwiło mu prowadzenie kompetentnych rozmów z przedstawicielami elit kulturowych i politycznych naszych wschodnich sąsiadów.

Prezentowana praca składa się z trzech, mniej lub bardziej obszernych, części wprowadzających czytelnika w historyczno-kulturowe konteksty stosunku trzech wschodniosłowiańskich narodów do Polaków, aczkolwiek w niniejszej nocie skupię się - ze zrozumiałych względów - na treściach zawartych w ostatniej z nich, poświęconej Białorusi. Tom rozpoczynają obszerne rozważania poświęcone relacjom ukraińsko-polskim. W tej części książki zamieszczono jednak przede wszystkim rozmowy z Nadią Sawczenko, Artiomem Skoropadskim, Wołodymyrem Wjatrowyczem, Ihorem Iljuszynem, Oksaną Zabużko i Jurijem Nojewym. W rozważaniach zatytułowanych Rosja, po wprowadzeniu w tematykę stosunków rosyjsko-polskich, przedstawiono wywiady z Władimirem Żyrinowskim Aleksandrem Duginem, Iwanem Wyrypajewem, Jakowem Krotowem, Władimirem Poznerem i Siergiejem Markowem.

Ostatnia część pracy została poświęcona relacjom białorusko-polskim. Trzydziestostronicowe wprowadzenie nosi tytuł Od Jagietly do „Burego”. Omawiając stosunki między sąsiadami, Pieczyński zaczyna od czasów I Rzeczypospolitej i kończy na przemówieniach Aleksandra Łukaszenki oraz wypowiedziach współczesnych historyków 
białoruskich. Uważa, że o ile w relacjach z Rosjanami i Ukraińcami Polacy są bardziej poszkodowani, a obecni pogrobowcy dawnych oprawców do zbrodni przyznać się nie chcą, o tyle w przypadku naszych stosunków z Białorusinami „mamy za co posypywać głowę popiołem" (s. 404). Zwraca też uwagę na znacznie mniej napastliwe tony białoruskich historyków, twórców kultury czy chociażby autorów filmowego obrazu Ślady na wodzie z 2016 r., opowiadającego o walkach sowieckiego aparatu bezpieczeństwa z ,polskimi bandami AK”, w porównaniu z antypolskimi tonami widocznymi w narracjach ukraińskich, jak choćby w produkcji Żelazna sotnia (s. 395). Igor Marzaliuk, białoruski historyk i polityk przywoływany w książce, zaznacza, że w naszych wzajemnych stosunkach nie było białoruskiego odpowiednika ukraińskiej „rzezi wołyńskiej” (s. 399). Równocześnie Marzaliuk wskazuje na zbrodnie dokonane po wojnie przez Romualda Rajsa „Burego” na białoruskiej ludności Białostocczyzny i jego rehabilitację przez niektóre środowiska mieszkańców wschodniej Polski.

Autor pracy przytacza interesujący głos z białoruskiego (choć często rosyjskojęzycznego) Internetu:

18 maja 2017 roku Aksana Browacz, dziennikarka białoruskiego wydania „Komsomolskiej Prawdy”, zapytała na Facebooku swoich znajomych: ,Jak wam się wydaje, za co Białorusini nie lubią Polaków? Albo: czy mogą ich lubić”. Źmicier wymienił w odpowiedzi (w języku rosyjskim): „1. Za Białoruś pod polską władzą, 2. Za represje w stosunku do naszych narodowych elit (przykładem - Taraszkiewicz). Poza tym Polacy, podobnie jak ZSRS, nie byli zainteresowani utworzeniem państwa białoruskiego. 3. Za to, że niektórzy Polacy do dziś uważaja Białorusinów za niedorobionych Polaków, a Brześć i Grodno - za swoje miasta. 4. Za to, że pewna część Polaków uważa nas za Rosjan;). 5. Za to, że Polacy przypisali sobie Radziwiltów, Kościuszkę i «Żubrówkę»-ten spis może być naprawdę ogromny”. Max dodat do tej listy (biat.): „, 6. Za «Wilnonasze» [parafraza rosyjskiego hasta „Krymnasz”, które stało się niezwykle popularne w Internecie, wśród zwolenników aneksji pótwyspu-przyp. red.], 7. Za działania akowców podczas drugiej wojny światowej” (s. 373).

Były inne głosy. Yury tłumaczył antypolskie nastroje pojawiające się na Białorusi tym, że: „ludzie wciąż mają w głowie mentalność sowka [homo sovieticus- przyp. red.]. To dziesięciolecia propagandy” (ros.). „Rosjanie nie lubią Polaków, Białorusini lubią Rosjan, dlatego Białorusini nie lubią Polaków. Innych przyczyn nie ma tak naprawdę" (s. 374) - tak jest zdaniem Lilii.

Białoruskiej części książki towarzyszą trzy wywiady. Pierwszy przeprowadzono z Franciszkiem Wiaczorką, białoruskim działaczem politycznym i dziennikarzem. Zauważa on, że Polacy nie dostrzegają Białorusi, nie czują jej, nie znają jej problemów, mimo że więcej ich łączy z Białorusią niż z Ukrainą. Stwierdza też - nie bez racji - że starsze pokolenie Białorusinów („,babcie”) optuje raczej za Putinem niż Łukaszenką. Sądzę, że warto przytoczyć dłuższy cytat z wypowiedzi Wiaczorki: 
$\mathrm{Na}$ Białorusi - jego zdaniem - funkcjonują dziś tak naprawdę dwie narracje: zachodnia - probiałoruska, i sowiecka - prorosyjska. Ta pierwsza jest niestety słabsza. Warto też wiedzieć, że na Białorusi jest obecnie prowadzona wielka kampania dyskredytacji Polski. W Internecie można znaleźć grafiki przekonujące, że Polacy są nacjonalistami i chcą odebrać Białorusi jej ziemie. To manipulacja na stereotypach jeszcze z czasów sowieckich, kiedy od czasów szkolnych każdy Białorusin wiedział, że zanim przyszli ruscy komuniści, rządził tutaj ,polski pan”. Przekonują, że Polska nie może być naszym przyjacielem.

Kto tę kampanie inspiruje? Służby Łukaszenki?

Nie wiadomo. Raczej Moskwa. Wydaje się, że celem kampanii jest wytworzenie wrażenia, że lepszy jest już związek z Rosją niż sojusz z polskim panem (s. 411).

W następnym wywiadzie Stanisław Szuszkiewicz, znany polityk, pierwszy przewodniczący Rady Najwyższej Republiki Białoruś, stwierdza, że w jego kraju antypolonizm nie istnieje. Uważa, że Polska nie dysponuje środkami skutecznego wpływu na Łukaszenkę. Nie pozwoli też na to Rosja. Na pytanie: „Za co Białorusini mogą nie lubić Polaków?", odpowiada:

Jeśli już ktoś prowadzi na Białorusi antypolską propagandę, to jest to tak zwany Ruski Świat („Russkij Mir”). W myśl zwolenników tej koncepcji wszystko, co dobre, przychodzi do nas z Rosji, a wszystko, co złe - z Zachodu. A zatem wszyscy nasi sąsiedzi, oprócz Rosji, są tak naprawdę naszymi wrogami. Tak nam objaśnia rzeczywistość partia prezydencka Biełaja Ruś. Zgodnie z jej ideologią Białorusini to taka odmiana Rosjan (s. 413).

Trzeci i zarazem ostatni wywiad w tej części pracy został przeprowadzony z Piotrem Piatrouskim, filozofem i historykiem idei, ekspertem Centrum Analitycznego Republikańskiego Zjednoczenia Społecznego „Biała Ruś”. Piatrouskiego przedstawiono jako działacza organizacji głoszącej wartości konserwatywne. Sam prezentuje się jako osoba jednoznacznie prorosyjska, przeciwnik nadawanej z Polski w języku białoruskim telewizji Biełsat, natomiast - co ciekawe - zwolennik udostępnienia białoruskim telewidzom polskiego programu (kanału) w sieci kablowej poświęconego polskiej kulturze i historii. Uważa, że ,[z]achodnie demokracje liberalne podlegają erozji, nabierają wiele autorytarnych cech" (s. 418). Sądzę, że należy żałować, iż część białoruska książki jest tak krótka i zawiera tylko trzy wywiady, potwierdzając tezę, że Białoruś interesuje nas, Polaków, najmniej i niezbyt wiele o niej wiemy. Pracę jako całość uważam za jednoznacznie pożyteczną. 